\title{
Complete Atrioventricular Septal Defects "Outcome of Different Techniques"
}

\author{
MOHAMED E. ABDEL-RAOUF, M.D.; HOSNY M. EL-SALLAB, M.D.; MUHAMMED SHARAA, M.D. and \\ LAMIAA K. EL-SHONI, M.Sc.
}

The Department of Cardiothoracic Surgery, Faculty of Medicine, Al-Azhar University, Cairo

\begin{abstract}
Background: In complete atrioventricular septal defect (CAVSD), a single atrioventricular valve annulus, a common atrioventricular valve, and a defect of the inlet ventricular septum are observed. The deficiency of the atrioventricular septum also results in the presence of a large primum atrial septal defect.
\end{abstract}

Details of the anatomy, particularly the morphology of the atrioventricular valve are crucial in planning surgical repair of this lesion.

Total repair of such cardiac lesion is now spreading with intentions to save children at younger age and lower body weight.

Improved technical methods and post-operative management have resulted in declining mortality over time.

Aim of Study: The purpose of this study was to compare the outcome of different surgical modalities in total repair of complete atrioventricular canal defects either single patch or double patches techniques.

Patients and Methods: This study was conducted at (A1Hussin University Hospital, Pediatric Unit of National Heart Institute, Cairo University Specialized Pediatric Hospital \& Atfal Misr Hospital).

Between 2015 and 2017, fifty children with complete atrioventricular canal defects were operated upon. 50 Children with complete atrioventricular canal defects were divided into two groups: Group A included 30 patients who had total repair with single patch technique, and Group B included 20 patients who had total repair with double patches technique.

Results: Of 50 patients, $72 \%$ of them had Down Syndrome (DS). There were 3 mortalities distributed as 2 patients $(6.7 \%)$ in Group A \& 1 patient (5\%) in Group B, while 2 patients were lost during follow-up.

Fourty five patients had followed-up by echocardiography to measure the degree of valve regurgitation.

At last follow-up, ten patients had moderate or more than moderate left $\mathrm{AV}$ valve regurgitation distributed as moderate

Correspondence to: Dr. Mohamed E. Abdel-Raouf, The Department of Cardiothoracic Surgery, Faculty of Medicine, Al-Azhar University, Cairo in 4 patients $(14.8 \%) \&$ severe in 1 patient $(3.7 \%)$ in Group I \& 4 patients $(22.2 \%), 1$ patient $(5.6 \%)$ in Group II respectively.

Conclusion: Modified single-patch repair in infants with complete AVSD is a safe and reproducible technique. The results are as good as the two-patch technique. Among longterm survivors, most have very good clinical and functional results and minimal or no regurgitation of either $\mathrm{AV}$ valves.

Key Words: Complete Atrioventricular Septal Defects (CAVSD) - Atrioventricular-Septal-Defects.

\section{Introduction}

ATRIOVENTRICULAR Septal Defects (AVSDs) represent approximately $5 \%$ of congenital cardiac abnormalitiesand are bound by a variable deficiency of the Atrioventricular (AV) septum immediately above and below the AV valves. These defects are frequently associated with other cardiac malformations. About $30-40 \%$ of the cardiac abnormalities observed in patients with Down Syndrome are AVSDs [1].

It is caused by an abnormal or inadequate fusion of the superior and inferior endocardial cushions with the mid portion of the atrial septum and the muscular portion of the ventricular septum [2] .

Tachypnea, repeated respiratory infections, poor feeding, and failure to thrive are frequent symptoms in patients with complete atrioventricular septal defect and large left-to-right shunts. These symptoms are usually present by 6-8 weeks and due to blood flow through the large interventricular communication with or without incompetence of the common atrioventricular valve [3] .

Medical treatment effectiveness in complete atrioventricular septal defect has been questioned, diuretics, digoxin, and angiotensin converting 
enzyme inhibitors have all been used to alleviate tachypnea and failure to thrive [4]

Treatment for a complete atrioventricular septal defect is surgical. Single-stage complete repair is currently preferred, but occasional cases of refractory congestive heart failure in a low-birth-weight infant may be palliated with the placement of a pulmonary artery band [5]

Total repair of such cardiac lesion is now spreading with intentions to save children at younger age and lower body weight. The purpose of this study was to evaluate the outcome of different surgical modalities in total repair either single patch or double patches techniques.

\section{Patients and Methods}

This study was conducted at (Al-Hussin University Hospital, Pediatric Unit of National Heart Institute, Cairo University Specialized Pediatric Hospital and Atfal Misr Hospital).

Between 2015 and 2017, fifty children with complete atrioventricular canal defects were operated upon. Children were divided into two groups: Group A included 30 patients who had total repair with single patch technique, and Group B included 20 patients who had total repair with double patches technique.

\section{Inclusion criteria:}

- Patients with complete type of atrioventricular septal defects.

- Patients with balanced ventricles.

\section{Exclusion criteria:}

- Patients with partial type of atrioventricular septal defects.

- Patients with unbalanced ventricles.

- Patients with irreversible pulmonary hypertension.

- Associated heart failure.

Patients were subjected to:

\section{A- Pre-operative assessment:}

- History taking with emphasis on age, sex and manifestation that was mostly repeated chest infection and failure to thrive.

- Clinical examination including general feature of Down's Syndrome, body weight, general and local examinations.

- Routine laboratory work up including Haemoglobin, coagulation profile, $\mathrm{CBC}$, liver and renal functions.
- Chest X-ray to assess the cardiac size, shape and pulmonary vasculature.

- Electrocardiography.

- Echocardiography describing detailed cardiac anatomy with special emphasis on degree of left atrioventricular valve regurgitation, the Rastelli classification of the complete form of common atrio-ventricular canal, size of ventricular septal defects, the balance of the canal, the presence of one versus two papillary muscles, the presence of associated ventricular septal defects and the presence of an important associated anomalies.

- Cardiac catheterization and angiocardiography is required in special situations in cases with severely elevated pulmonary arterial pressure to evaluate the pulmonary vascular resistance and and the presence of an important associated cardiac anomalies.

\section{B- Intra-operative assessment:}

- Surgical procedures: Repair of AV valves, repair techniques (one or two patches used).

- Bypass time, crossclamp time, time of cardioplegia.

- Need for inotropic support.

C- Post-operative assessment:

- Full ICU monitoring for pulse, invasive blood pressure, core and peripheral temperatures, central venous pressures, urine output, oxygen saturations, Arterial Blood Gases (ABG), the chest tube drainage, fluid and electrolyte balance.

- Duration of mechanical ventilation.

- Incidence of post-operative pulmonary hypertensive crisis.

- ICU medications and need for inotropic support.

- ECG for arrhythmias or any type of conduction abnormalities.

- CXR daily in the ICU and immediately before discharge from the hospital.

- Early post-operative echocardiography before discharge from hospital.

- Six months and one year follow-up by clinical examination, chest X-ray, echocardiography, ECG and need for medications (e.g. patients with heart failure, tricuspid or mitral regurgitation and residual lesions).

\section{Results}

Of 50 patients, $72 \%$ had Down Syndrome. Median age at surgery was $16.34 \pm 11.11$ months 
(ranged between 6-60 months). Median weight at surgery was $8.12 \pm 2.60 \mathrm{~kg}$ (ranged between $4-15 \mathrm{~kg}$ ). They were distributed as mentioned in (Table 1).

Table (1): Demographic data distribution in relation to the study groups.

\begin{tabular}{|c|c|c|c|c|}
\hline & \multirow{2}{*}{$\begin{array}{l}\text { Group A } \\
\text { No. }=30\end{array}$} & \multirow{2}{*}{$\begin{array}{l}\text { Group B } \\
\text { No. }=20\end{array}$} & \multicolumn{2}{|c|}{ Chi-square test } \\
\hline & & & $\chi^{2} / t^{*}$ & $p$-value \\
\hline \multicolumn{5}{|l|}{ Sex: } \\
\hline Females & $14(46.7 \%)$ & $15(75.0 \%)$ & 3.955 & 0.047 \\
\hline Males & $16(53.3 \%)$ & $5 \quad(25.0 \%)$ & & \\
\hline \multicolumn{5}{|l|}{ Age/month: } \\
\hline Mean \pm SD & $14.53 \pm 9.46$ & $19.00 \pm 13.05$ & 1.404 & 0.167 \\
\hline Range & $6-40$ & $6-60$ & & \\
\hline \multicolumn{5}{|l|}{$W t / K G$} \\
\hline Mean \pm SD & $7.80 \pm 2.69$ & $8.59 \pm 2.45$ & 1.055 & 0.297 \\
\hline Range & $4-15$ & $5-15$ & & \\
\hline \multicolumn{5}{|c|}{ Down syndrome: } \\
\hline No & $7 \quad(23.3 \%)$ & $7 \quad(35.0 \%)$ & 0.810 & 0.368 \\
\hline Yes & $23(76.7 \%)$ & $13(65.0 \%)$ & & \\
\hline
\end{tabular}

Comparisons between both groups showed as regard to total pump times and ischemic times were longer in Group B than in Group A. (91.00 $\pm 35.61) \mathrm{min}$ in Group A, vs. (114.25 \pm 22.49$) \mathrm{min}$ in Group B $p=0.013 ;(67.00 \pm 35.85)$, vs. $(92.75 \pm$ 22.80 ) respectively $p=0.006$.

As regard to mechanical ventilation time, duration of inotropic support need \& ICU stay, it was longer in Group B than in Group A (mean 12.07) $\mathrm{SD} \pm 9.37$ in Group A, while in Group B, (mean 19.80) SD $17.96 p=0.052$; mean (4.53 \pm 1.41$)$, versus (mean $5.25 \pm 2.12$ ) $p=0.157$ respectively Fig. (1).

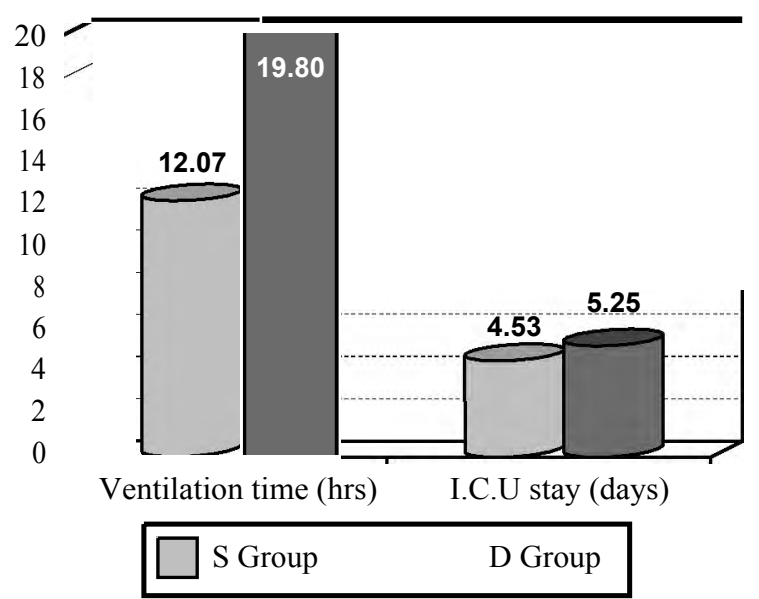

Fig. (1): Post-operative mechanical ventilation time and ICU stay data distribution in relation to different groups.

As regard to post-operative complications in the form of chest infection, heart block, pericardial effusion \& heart failure, numbers did not reach statistical significant difference between the two groups. In Group A chest infection was 3 patients $(10 \%)$ compared to 2 patients $(10 \%)$ in Group B, transient heart block which resolved well with no need for pacemaker implantation was 1 patient $(3.3 \%)$ in Group A and 1 patient (5\%) in Group B. Pericardial effusion which improved on diuretics was in 3 patients $(10 \%)$ in Group A to 3 patients $(15 \%)$ in Group B. Heart failure 1 patient $(3.3 \%)$ and $(0 \%)$ in both groups respectively Fig. (2).

During follow-up mortality was 2 patients $(6.7 \%)$ in Group A \& 1 patient (5\%) in Group B Fig. (2).

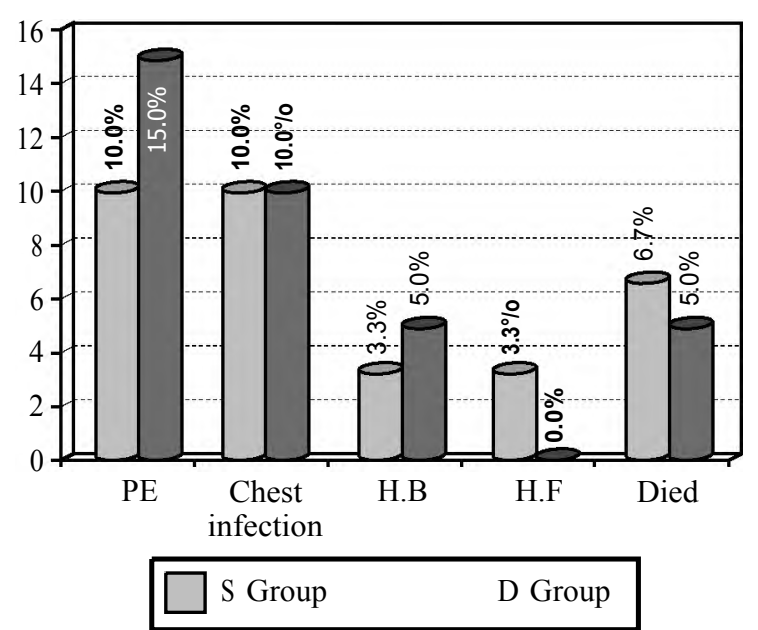

Fig. (2): Post-operative complications distribution in relation to different groups.

At last follow-up, ten patients had moderate or more than moderate left $\mathrm{AV}$ valve regurgitation distributed as moderate in 4 patients $(14.8 \%) \&$ severe in 1 patient $(3.7 \%)$ in Group A \& 4 patients $(22.2 \%), 1$ patient $(5.6 \%)$ in Group B respectively Fig. (3).

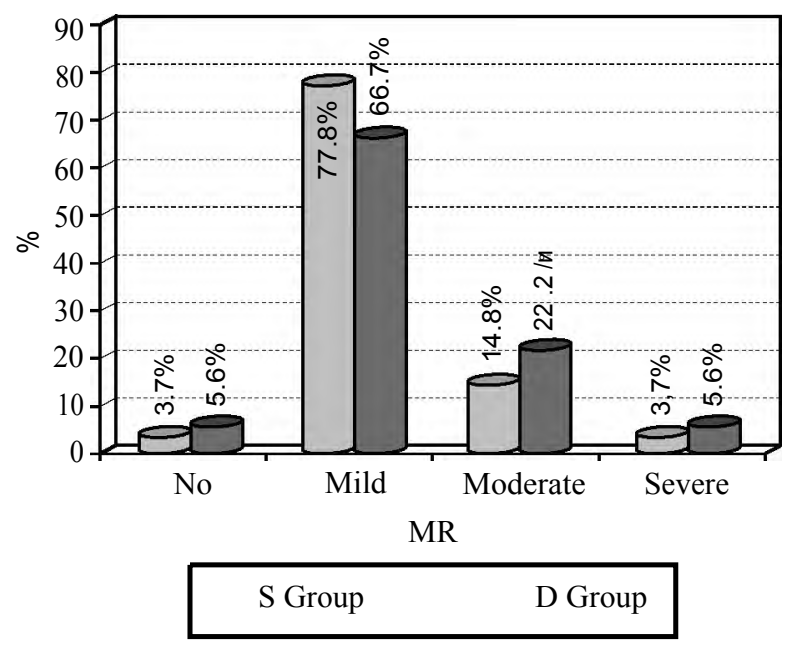

Fig. (3): Post-operative follow-up residual MR degree distribution in relation to different groups. 
Table (2): Operative data among the study groups.

\begin{tabular}{|c|c|c|c|c|}
\hline & $\begin{array}{l}\text { Group A } \\
\text { No. }=30\end{array}$ & $\begin{array}{l}\text { Group B } \\
\text { No. }=20\end{array}$ & $\begin{array}{r}\text { Indel } \\
t- \\
t\end{array}$ & $\begin{array}{l}\text { endent } \\
\text { test } \\
\text { - value }\end{array}$ \\
\hline $\begin{array}{l}C P B \text { time/min: } \\
\text { Mean } \pm \mathrm{SD} \\
\text { Range }\end{array}$ & $\begin{array}{l}91.00 \pm 35.61 \\
50-240\end{array}$ & $\begin{array}{l}114.25 \pm 22.49 \\
55-160\end{array}$ & 2.591 & 0.013 \\
\hline $\begin{array}{l}\text { Clamp time/min: } \\
\text { Mean } \pm \text { SD } \\
\text { Range }\end{array}$ & $\begin{array}{l}67.00 \pm 35.85 \\
35-220\end{array}$ & $\begin{array}{l}92.75 \pm 22.80 \\
40-145\end{array}$ & 2.846 & 0.006 \\
\hline
\end{tabular}

\section{Discussion}

In this study, the age group ranged between 660 months and their body weight ranged between 4-15KG.

In Group A, age was ranged between 6 and 40 months, mean (14.53) SD \pm 9.46 , while in Group $\mathrm{B}$, age ranged between 6 and 60 months, mean (19) SD \pm 13.05 , The body weight in Group (A) ranged between 4 and $15 \mathrm{~kg}$, mean (7.80) SD \pm 2.69 , while in Group (B).

The body weight ranged between 5 and $15 \mathrm{~kg}$, mean (8.59) SD \pm 2.45 .

Compared to Singh et al. [6] who published their results including 65 infants and children with a mean age of 10.9 months (range, 1 month to 15.5 years) who underwent CAVSD repair from 1990 to 2004 . Twenty-six repairs (40\%) were done on or before 3 months of age (Group A) and 39 repairs $(60 \%)$ were done after 3 months of age (Group B), they had 46 out of them were neonates and 20 patients were infants.

The same also for Khushboo et al. [7], that were operated on 48 patients with a median age of 105 days (range 34-405) and weight of 4.3kg (2.7-7.7). The cohort was subdivided based upon age at surgery into Group A ( $\leq 90$ days, $n=18)$ and Group B ( $>90$ days, $n=30)$. Pre-operative patient characteristics were similar between groups except weight at surgery ( 3.8 vs. $4.6 \mathrm{~kg})$.

The majority of patients in our study were Down Syndrome with overall number 36 (72\%). In Group A, 23 patients (76.7\%) \& in Group B, 13 patients $(65 \%)$ are Down Syndrome. Values were statistically-insignificant $(p>0.05)$.

Tumanyan et al. [8] study revealed, concerning the long-term results, no significant difference in actuarial freedom from reoperation after repair of CAVSD between DS and NK (non karyotyping) groups $(p<0.13)$. However, the presence of Down
Syndrome in patients significantly increases the risk of severe co-morbidities that have a significant impact on the recovery period, as well as on life expectancy even after successful correction.

As regard to total pump time, Group A showed a mean pump time of $91.00 \pm 35.61 \mathrm{~min}$, while it was $114.25 \pm 22.49 \mathrm{~min}$ in Group B $(p=0.013)$. It was homogenous when compared with other studies, results from Pan $\mathrm{G}$ et al. [9]. The study reported a total pump time of $(95.02 \pm 19.73)$ vs. $(109.9 \pm 34.07),(p=0.011)$ for both groups respectively. (Significantly longer in Group B than in Group A).

While for cross clamp time, Group A showed ischemic time of $(67.00 \pm 35.85)$, while it was $(92.75$ $\pm 22.80)$ in Group B $(p=0.006)$. In the same fashion, $\mathrm{Pan} \mathrm{G}$ et al. [9] reported (70.56 \pm 21.05$)$ vs. (83.76 \pm $22.74)$ minutes, $(p=0.004)$ in the two groups respectively.

Al-Senaidi et al. [10] study as regard preoperative and immediate post-operative twodimensional (2D) echocardiograms, as well as follow-up 2D and three-dimensional (3D) studies, were reviewed for the LAVV, no significant difference was observed with respect to LAVV annulus size, tenting height, and the size of the vena contracta.

In-hospital mortality rate in our study was 2 patients (6.7\%) In Group A \& 1 patients (5\%) in Group B, compared with operative mortality in other studies of Shi G et al. [11], it was $0 \%$ \& $11.11 \%$ in both groups respectively, Pan et al. [9] $2.17 \& 1.69$ in both groups respectively.

James et al. [12] reportedover all hospital mortality 3\%. While SalilGinde et al. [13], reported overall perioperative mortality $10 \%$, with a significant decrease to $3 \%$ in the late surgical era ( $p$ $<0.001)$.

\section{Conclusion:}

- Well-equipped pediatric surgical units should raise their capacity and facilities with well-trained devoted teams (surgeons, anesthetists, intensivists, perfusionists and nursing staff) to cope with such procedures and increase their experience with younger age and lower body weight children.

- Despite different ages, different weight at repair, and different physiology, patients with complete AVSD present a similar risk of LAVVR.

- TEE is mandatory intraoperative during CAVC repaireven though, there is often too much discrepancy between its findings and those obtained 
through transthoracic exams in the days or weeks after repair.

- Great care should be taken during LAVV repair, great effort should be done to get mild or no LAVV regurgitation \& that it is not accepted to discharge the patient with more than moderate regurgitation.

- Statements such as "in Down patients valve tissue is more abundant and allows for an easier reconstruction"are often seen however, not all studies confirm this relationship. We did not find any significant differences between individuals with or without Down Syndrome in our study or other studies.

- Chest condition is an important post-operative factor to be followed properly especially in patients with Down Syndrome \& is considered the greatest predisposing factor for prolonged postoperative hospital stay.

Modified single-patch repair in infants with complete AVSD is a safe and reproducible technique. They provides shorter ischemic time and bypass time. The results are as good as the double patches technique. Among long-term survivors, most have very good clinical and functional results and minimal or no regurgitation of either $\mathrm{AV}$ valves.

\section{References}

1- MURESAN D., MARGINEAN C., ZAHARIE G., et al.: Complete atrioventricular septal defect in the era of prenatal diagnosis. Med. Ultrason., 18 (4): 500-7, 2016.

2- FYLER D.C., BUCKLEY L.P., HELLENBRAND W.E., et al.: Report of the New England Regional Infant Cardiac Program. Pediatrics, 65: 375-461, 1980.

3- HAY: Lange Current Pediatric Diagnosis and Treatment, 18th ed. New York: McGraw-Hill, 2007.

4- BUCHHORN R., HULPKE-WETTE M., RUSCHEWSKI W., et al.: Effects of therapeutic beta blockade on myo- cardial function and cardiac remodelling in congenital cardiac disease. Cardiol. Young., 13 (1): 36-43, 2003.

5- SUZUKI T., BOVE E.L., DEVANEY E.J., et al.: Results of definitive repair of complete atrioventricular septal defect in neonates and infants. Ann. Thorac. Surg., 86 (2): 596-602, 2008

6- SINGH R.R., WARREN P.S., REECE T.B., et al.: Early repair of complete atrioventricular septal defect is safe and effective. Ann. Thorac. Surg., 82 (5): 1598-601, 2006.

7- KHUSHBOO PARIKH, NISHANT C. SHAH and ALLEN KUNSELMANAND JOSEPH B. CLARK: Complete atrioventricular canal defect: Influence of timing of repair on intermediate outcomes, JACC (Journal of the American College of Cardiology), Volume 67, Issue 13, Pages 973973, 2016.

8- TUMANYAN M.R., FILARETOVA O.V., CHECHNEVA V.V., et al.: Repair of complete atrioventricular septal defect in infants with down syndrome: Outcomes and long-term results. Pediatr. Cardiol., 36 (1): 71-5, 2015.

9- PAN G., SONG L., ZHOU X. and ZHAO J.: Complete atrioventricular septal defect: Comparison of modified single-patch technique with two-patch technique in infants. J. Card. Surg., 29 (2): 251-5, 2014.

10- AL-SENAIDI K.S., ROSS D.B., REBEYKA I.M., et al.: Comparison of two surgical techniques for complete atrioventricular septal defect repair using two-and threedimensional echocardiography. Pediatr. Cardiol., 35 (3): 393-8, 2014.

11- SHI G., CHEN H., HONG H., et al.: Results of one-anda-half-patch technique for repair of complete atrioventricular septal defect with a large ventricular component. Eur. J. Cardiothorac. Surg., 47 (3): 520-4, 2015.

12- JAMES D. ST. LOUIS M.D., UPINDER JODHKA M.D., JEFFREY P. JACOBS M.D., et al.: Contemporary outcomes of complete atrioventricular septal defect repair: Analysis of the Society of Thoracic Surgeons Congenital Heart Surgery Database Journal of Thoracic and Cardiovascular Surgery, Volume 148, Issue 6, Pages 2526-31, 2014

13- SALIL GINDE, JANNA LAM, GARICK HILL, et al.: Long-term survival and need for reoperation after surgical repair of complete atrioventricular septal defect: 40 year follow-up at a single institution. JACC (Journal of the American College of Cardiology), Volume 63, Issue 12, Pages A491-A491, 2014. 


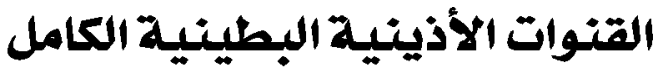 \\ نتائج التقنيات الجرأينية البطينية المختلفة}

تعتبر القنوات الأذينية البطينية هى أحد العيوب الخلقية بالقلب وهى قد تكون كاملة أوجزئية، وتسم الكاملة منها بنقص فى الحاجز القلبى

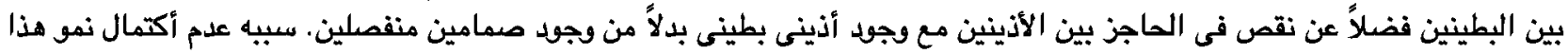
الجزء أثناء التكوين الجنينى للطفل المصاب بهذا العيب الخلقى وقد لوحظ أن تلك الأطفال المصابين بهذا العيب الخلقى من متلازمة داون.

وغالباً ما يعانى هؤلاء الأطفال من سرعة بالتنفس وإلتهابات متكررة بالجهاز التفسى والتى عادة ما تظهر قبل 1-1 أسابيع من العمر.

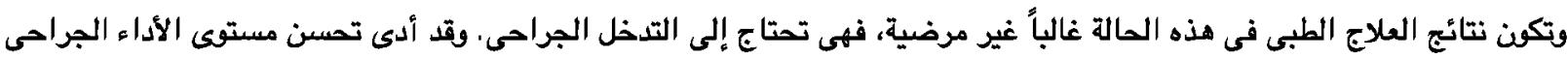

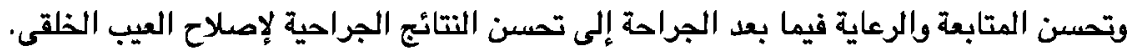
وفى هذه الدراسة قهنا بمقارنة نتائج الأستراتيهيات والتقنيات الجراحية المختلفة سواء بإستخدام الرقعة الواحدة أو الرقعتين وقد تبين

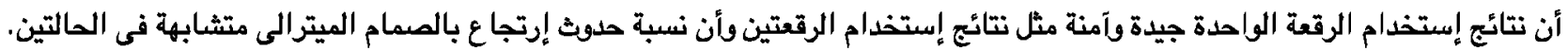
وكذلك نسبة حلوث مضاعفات أو وفيات كما ودد في هذه الدئة الدراسة. 